\title{
UPAYA MENINGKATKAN MOTIVASI DAN PRESTASI BELAJAR SISWA MELALUI MODEL PEMBELAJARAN INKUIRI TERBIMBING BERBASIS PEER TUTORIAL
}

\author{
Albertus Pati Molan ${ }^{1}$, Akhmad Jufriadi $^{2}$, Hestiningtyas Yuli Pratiwi ${ }^{3}$ \\ Program Studi Pendidikan Fisika, Universitas Kanjuruhan Malang ${ }^{1,2,3}$ \\ e-mail : albertusdonara@gmail.com
}

\begin{abstract}
Abstrak. Berdasarkan observasi yang dilakukan, motivasi belajar siswa masih sangat rendah sehingga prestasi belajar yang diperoleh siswa SMP Negeri 23 Malang Tahun Ajaran 20 16/2017, pada mata pelajaran IPA menjadi sangat rendah pula. Rata-rata ketuntasan berada di bawah Kriteria Ketuntasan Minimum (KKM) yaitu 68.51. Sedangkan nilai KKM maka yang dipakai di SMP Negeri 23 Malang adalah 75. Dilihat dan persyaratan ketuntasan tersebut siswa yang mencapai KKM untuk kelas VIII 3 hanya 13 siswa dan 33 siswa atau 37,17\%. Dengan demikian peneliti akan menerapkan model pembelajaran inkuiri terbimbing berbasis peer tutorial untuk meningkatkan motivasi dan prestasi belajar siswa kelas VIII SMP Negeri 23 Malang. Penelitian ini bertujuan untuk meningkatkan motivasi dan prestasi belajar siswa kelas VIII 3 SMP Negeni 23 Malang dengan menerapkan model pembelajaran inkuiri terbimbing berbasis peer tutorial subyek penelitian mi adalah siswa kelas VIII 3 SMP Negeni 23 Malang yang berjumlah 35 siswa. Penelitian mi menggunakan penelitian tindakan kelas (PTK) yang dilakukan dalam dua sikius dengan tahapantahapan: (1) perencanaan, (2) pelaksanaaan, (3) observasi, (4) refleksi. Hasil penelitian keterlaksanaan pembelajaran pada sikius I adalah $78,35 \%$ berada pada kategori baik dan pada sikius II adalah $93,75 \%$ berada pada kategori sangat baik. Sedangkan untuk presentase motivasi belajar siswa path sikius I adalah 65,38\% berada pada kategori cukup baik dan pada siklus I adalah $82.04 \%$ berada pada kategori baik. Dan presentase prestasi belajar siswa path siklus I adalah $65,71 \%$ dengan kategori cukup baik, dan pada siklus II meningkat menjadi 85,51\% dengan kategori baik. Berdasarkan hasil penelitian ini dapat disimpulkan bahwa penelitian model pembelajaran inquiri terbimbing berberbasis peer tutorial dapat meningkatkan motivasi dan prestasi belajar siswa.
\end{abstract}

Kata Kunci : Inkuiri Terbimbing; Peer tutorial; Motivasi Belajar; Prestasi Belajar

\section{PENDAHULUAN}

IPA pada hakikatnya dibangun atas dasar produk ilmiah, proses ilmiah dan juga sikap ilmiah. Sebagai proses ilmiah diartikan bahwa semua kegiatan ilmiah untuk menyempumakan pengetahuan tentang alam maupun untuk menemukan pengetahuan baru. Sebagai prosedur ilmiah dimaksudkan bahwa metodologi atau cara yang dipakai untuk mengetahui sesuatu pada umumnya berupa riset yang lazim disebut metode ilmiah (scientific method) (Trianto,2010). Bersumber pada pengertian IPA tersebut maka peningkatan pembelajaran Ilmu Pengetahuan Alam di sekolah, merupakan salah satu dasar untuk memacu kemajuan suatu bangsa dan menjadi tolok ukur dalam penguasaan ilmu pengetahuan dan teknologi. Pembelajaran yang efektif, menyenangkan dan tidak membosankan membuat siswa lebih termotivasi dalam belajar yang dapat berdampak pada peningkatan prestasi siswa. Guru dan tenaga kependidikan berkewajiban suasana pendidikan yang bermakna, menyenangkan, kreatif, dinamis, dan dialogs. Proses pembelajaran pada satuan pendidikan diselenggarakan secara interaktif, inspiratif, rnenyenangkan, menantang, dan memotivasi peserta didik untuk berpartisipasi aktif, serta memberikan ruang yang cukup bagi prakarsa, kreatifitas dan kemandirian sesuai dengan bakat, minat dan perkelmbangan fisik serta psikologis peserta didik Untuk setiap kegiatan belajar mengajar, guru dituntut mampu memberikan bimbingan, memberikan situasi sedemikian nipa 
sehingga siswa dapat mengembangkan keterampilan. Selain itu juga dituntut untuk mampu membangkitkan dan memelihara minat siswa dalam belajar mengajar IPA. Hal ini sesuai dengan penelitian yang pemah dilakukan sebelumnya, yaitu penelitian yang dilakukan oleh Patrick, dkk (2009) bahwa implementasi pembelajaran inkuiri terbimbing dapat meningkatkan motivasi siswa dalam pembelajaran IPA. Peer Tutoring dikenal dengan pembelajaran teman sebaya atau antar peserta didik. Metode ini dilakukan dengan cara memberdayakan kemampuan peserta didik yang memiliki daya scrap tinggi agar mengajarkan materi atau latihan kepada teman- temannya yang belum faham (Tritanto, 2014). Peer tutoring termasuk pembelajaran kooperatif. Ide utama pembelajaran kooperatif yaitu siswa bekerja sama dan bcrtanggung jawab pada kemajuan belajar temannya sehingga dapat membantu individu menjalani proses pembelajaran yang lebih positif dan pada ketika siswa hanya mengerjakannya sendiri (Miftahul, 2013).

IPA (Sains) sudah banyak dikemukakan oleh para aihi, antara lain menurut Supriyadi (2010), para ilmuwan sepakat bahwa IPA adalah suatu bentuk metode yang berpangkal pada pembuktian hipotesis. Dalam sumber yang sama dinyatakan juga bahwa IPA adalah suatu kumpulan teori yang sistematis, penerapannya secara umum terbatas path gejala-gejala alam, lahir dan berkembang melalui metode ilmiah seperti observasi dan eksperimen serta menuntut sikap ilmiah seperti rasa ingin tahu, terbuka, jujur, dan sebagainya. Metode ilmiah ini menekankan pada adanya masalah, adanya hipotesa, adanya analisa data untuk menjawab masalah atau membuktikan hipotesa, dan diakhiri dengan adanya kesimpulan atau generalisasi yang merupakan jawaban resmi dan masalah yang diajukan. Inkuiri sebagai suatu proses umum yang dilakukan manusia untuk mencari atau memahami informasi. Materi yang disajikan guru bukan begitu saja diberikan dan diterima oleh siswa, tetapi siswa menemukan sendiri konsepkonsep yang direncanakan oleh guru (Wahyudin \& Sutikno 2010). Tujuan utama model inkuiri adalah mengembangkan keterampilan intelektual, berfikir kritis, dan mampu memecahkan masalah secara ilmiah (Dimyati \& Mudjiono, 2009). Langkah-langkah pembelajaran inkuiri menurut Wina Sanjaya (2012) adalah sebagai berikut:

Pertama, langkah orientasi adalah langkah untuk membina suasana atau iklim pembelajaran yang responsif. Pada langkah ini guru mengondisikan agar siswa siap melaksanakan proses pembelajaran. Berbeda pada tahapan prepation dalam strategi pembelajran ekspositori (SPE) sebagai langkah untuk mengkondisikan agar siswa siap menerima pelajaran, pada langkah orientasi dalam SPI, guru merangsang dan mengajak siswa untuk berfikir memecahkan masalah. Kedua, merumuskan masalah, merupakan langkah membawa siswa pada suatu persoalan yang mengandung teka-teki. Persoalan yang disajikan adalah persoalan yang menantang siswa untuk memecahkan teka-teki itu. Dikatakan teka-teki dalam rumusan masalah yang ingin dikaji disebabkan masalah itu tentu ada jawabannya, dan siswa didorong untuk mencari jawaban yang tepat. Proses mencari jawaban itulah yang sangat penting dalam strategi inkuiri, oleh sebab itu melalui proses tersebut siswa akan memperoleh pengalaman yang sangat berharga sebagai upaya mengembangkan mental melalui proses tersebut siswa akan memperoleh pengalaman yang sangat berharga sebagai upaya mengembangkan mental melalui proses berfikir. Dengan demikian, teka-teki yang menjadi masalah dalam berinkuiri adalah tekateki yang mengandung konsep yang jelas yang hams dicari dan ditemukan. Ketiga, meengajukan Hipotesis adalah jawaban sementara dan suatu permasalahan yang sedang dikaji. Sebagai jawaban sementara, hipotesis perlu diuji kebenarannya. Kemampuan atau potensi individu untuk berfikir pada dasamya sudah dimiliki sejak individu itu lahir. Potensi berfikir itu dimulai dañ kemampuan setiap individu untuk menebak atau mengira-ngira (berhipotesis) dan suatu permasalahan. Manakala individu dapat membuktikan tebakannya, maka ja akan sampai pada posisi yang bisa mendorong untuk berfikir lebih lanjut. Oleh sebab itu, potensi untuk mengembangkan kemampauan menebak pada setiap individu harus dibina. Keempat, mengumpulkan data adalah aktivitas menjaring informasi yang dibutuhkan untuk menguji hipotesis yang diajukan. Dalam strategi pembelajaran inkuiri, mengumpulkan data merupakan proses mental yang sangat penting dalam pengembangan intelektual. Proses pengumpulan data bukan hanya memerlukan motivasi yang kuat dalam belajar, akan tetapi juga membutubkan ketekunan dan menggunakan potensi berfikirnya. Oleh sebab itu, tugas dan peran guru dalam tahapan ini adalah mengajukan pertanyaan-pertanyaan yang dapat mendorong siswa untuk 
berfikir mencari informasi yang dibutuhkan. Sering terjadi kemacetan berinkuiri adalah manakala siswa tidak apresiasifterhadap pokok permasalahan. Tidak apresiasif itu biasanya ditunjukkan oleh gejala-gejala ketidak bergairahan dalam belajar. Manakala guru menemukan gejala-gejala ketidak semacam ini, maka guru hendaknya secara terus-menerus memberikan dorongan kepada siswa untuk belajar melalui penyuguhan berbagai jenis pertanyaan secara merata kepada seluruh siswa sehingga mereka terangsang untuk berpikir.

Kelima, menguji hipotesis adalah proses menentukan jawaban yang dianggap diterima sesuai dengan data atau informasi yang diperoleh berdasarkan pengumpulan data. yang terpenting dalam menguji hipotesis adalah mencari tingkat keyakinan siswa atas jawaban yang diberikan. Disamping itu, menguji hipotešis juga berarti mengembangkan kemampuan berfikir rasional. Artinya, kebenara jawaban yang diberikan bukan hanya berdasarkan argumentasi, akari tetapi hams didukung oleh data yang ditemukan dan dapat dipertanggungjawabkan. Keenam merumuskan kesimpulan adalah proses mendeskripsikan temuan yang diperoleh berdasarkan hasil pengujian hipotesis. Menurut rumuskan kesimpulan merupakan gong-nya dalam proses pembelajaran. Sering terjadi, oleh karena banyaknya data yang diperoleh, menyebabkan kesimpulan yang dirumuskan tidak berfokus terhadap masalah yang hendak dipecahkan. Karena itu, untuk mencapai kesimpulan yang akurat sebaiknya guru mampu menunjukkan pada siswa data yang relevan. Setiap model pembelajaran memiliki keunggulan dan kelemahan.

\section{METODE PENELITIAN}

Data yang diperoleh dipaparkan sesuai dengan hasil penelitian. Pemelitian ini bertujuan untuk memperoleh data, fakta dan informasi objektif yang mendekati dengan masalah yang diteliti. Pendekatan dalam penelitian ini mengunakan pendekatan kualitatif karena penelitian ini memenuhi kriteria: (1) Kondisi ilmiah, (2) Peneliti sebagai instrumen utama, (3) Analisis yang dilakukan dalam penelitian ini dilakukan dengan angka-angka dan tabel-tabel karena lebih praktis. Sesuai dengan pendekatan dan rancangan penelitian maka kehadiran peneliti mutlak diperlukan. Hal ini disebabkan karena peneliti yang merencanakan pembelajaran sekaligus menyampaikan maten selama kegiatan berlangsung, mengumpulkan data, menganalisis dan melaporkan hasil penelitian. untuk mengumpulkan data yang diperlukan, peneliti di bantu oleh guru fisika dan teman sejawat. Dalam penelitian ini dipilih kelas VIII 3 SMP Negeri 23 Malang yang berjumlah 35 siswa. Pemilihan lokasi ini berdasarkan pertimbangan saat ditemukan permasalahan yang akan diteliti yaitu kurangnya motivasi belajar siswa dan rendahnya prestasi siswa. Instrumen yang digunakan dalam penelitian ini adalah (1) Instrumen Perlakuan (a) Rencana Pelaksanaan Pembelajaran (RPP) (b) Skenario Pembelajaran (c) Lembar Kerja Siswa LKS. (2) Instrumen Pengambilan Data (a) Tes Prestasi belajar (b) Observasi (3) Instrumen Motivasi Siswa (4) Catatan Lapangan. Analisis data dalam penelitian ini dilakukan dan setelah pengumpulan data dan dianalisis melalui tahapan yaitu a) Mereduksi data, b) Menyajikan data, e) Menarik kesimpulan. Pengecekan keabsahan data dilakukan untuk menjamin keabsahan data. Data pada pelaksanaan ini difokuskan pada motivasi dan prestasi belajar siswa dalam mengikuti pembalajaran fisika. Keabsahan tersebut dapat dilihat dari (1) lembar observasi keterlaksanaan pembelajaran, dinilai dengan kriteria yang ada. (2) lembar observasi motivasi belajar siswa, dinilai dengan kinerja yang ada. (3) Hasil pengamatan saat proses belajar mengajar (catatan lapangan). (4) Hasil tes prestasi siswa yang telah dimlai dengan kriteria yang ada. (5) Hasil diskusi dengan guru dan teman sejawat sebagai pengamat. Tahap-tahap penelitian (1) Tahap persiapan (2) Tahap pelaksanaan. Setiap tahap dapat terdiri dan didahului oleh beberapa langkah, misalnya langkah perencanaan didahului oleh orentasi yang diidentifikasi oleh guru. Adapun tahap-tahap yang telah disebutkan diatas dapat di uraikan secara terperinci sebagai berikut: Siklus 1 (a) Merencanakan (b) Melakukan tindakan (c) Mengamati (d) Refleksi .

\section{HASIL DAN PEMBAHASAN}

Peneliti mengunjungi sekolah yang dijadikan sebagai objek penelitian yaitu salah satu SMP Negeri di kota Malang, kemudian peneliti meminta ijin kepada kepala sekolah untuk 
melakukan penelitian, dan setelah mendapatkan ijin dari bapak kepala sekolah peneliti diminta berkonsultasi kepada guru mata pelajaran IPA Terpadu. Peneliti memperoleh beberapa kesepakatan antara lain (1) kelas yang dijadikan penelitian adalah kelas VIII-3 yang berjumlah 35 siswa. (2) Observer/pengamat dalam penelitian ini ada 2 orang. (3) Materi yang diajarkan pada siswa tentang Indra Penglihatan dan Alat Optik. (4) Pelaksanaan tindakan penelitian disesuaikan dengan jadwal mata pelajaran IPA, yaìtu kelas VIII.3 Selasa pukul 07.00-08.25, dan Jumat pukul 08.30 - 10.5. (5) Pelaksanaan tindakan siklus I dilaksanakan dua kali pertemuan, sedangkan siklus II tiga kali pertemuan (6) Mendata hasil ulangan harian siswa yang telah dicapai sebelumnya yang didapat dan mata pelajaran IPA Terpadu. Berdasarkan pengolahan data hasil observasi yang ditemukan oleh pengamat, dapat diketahui bahwa pada siklus I pertemuan pertama presentase keterlaksaan pembelajaran mencapai $64,75 \%$ dan pertemuan kedua mencapai $79,50 \%$ dengan total presentase keterlaksanaan pembelajaran pada siklus I sebesar 72,13\%. Berdasarkan kriteria taraf keberhasilan guru dalam melaksanakan pembelajaran termasuk dalam kategori cukup baik. Pada siklus II keterlaksanaan pembelajaran pertemuan pertama presentase keterlaksaan pembelajaran mencapai 90,63\% dan pertemuan kedua mencapai $96,88 \%$ dengan total presentase keterlaksanaan pembelajaran pada siklus II sebesar 93,75\%. Berdasarkan kriteria taraf keberhasilan guru dalarn melaksanakan pembelajaran termasuk dalam kategori cukup baik.

Proses pembelajaran yang dilaksanakan dengan menerapkan model pembelajaran inkuiri terbimbing berbasis Peer tutorial telah diperoleh data observasi keterlaksanaan pembelajaran yang diamati oleh observer dengan menggunakan pedoman penilaian keterlaksanaan pembelajaran yang terdiri dan beberapa tahap pembelajaran yaitu tahap pendahuluan, tahap mti dan tahap penutup. Berdasarkan hasil pengamatan yang dilakukan pada silklus I dan siklus II diperoleh data berikut. (a) tahap pelaksanaan, (b) tahap inti, (c) tahap penutup. Motivasi belajar siswa diukur secara berkelompok dengan bantuan pengamat menggunakan instrumen penilaian motivasi belajar siswa, yang terdiri dañ 5 aspek penilaian seperti yang dilampirkan antara lain: (a) Minat, (b) Perhatian, (c) Senang, (d) Terlibat dan penuh konsetrasi, (e) Tekun. Berdasarkan nilai-nilai kelas dapat melakukan penelitian, peneliti berpedoman pada data prestasi siswa yang diperoleh dan guru mata pelajaran IPA Terpadu pada saat melakukan observasi. Berdasarkan data yang diperoleh peneliti mengetahui bahwa nilai rata- rata kelas VIII-3 dengan jumlah siswa 35 orang adalah 68,51 kualifikasi cukup baik.

Data yang diperoleh ini merupakan data pra siklus yang akan digunakan peneliti sebagai bahan pertimbangan untuk melakukan tes pembelajaran pada tindakan siklus I. Dengan demikian dapat diketahui bahwa prestasi siswa pada siklus I lebih besar dibandingkan dengan pm siklus hal ini di karenakan peneliti menerapkan model pembelajaran inkuiri terbimbing berbasis peer tutorial yang merupakan model pembelajaran yang barn diterapkan di kelas tersebut sehingga siswa tidak merasa bosan saat mengikuti kegiatan pembelajaran karena model pembelajaran ini sangat menekankan kepada siswa untuk menean dan menemukan sendiri konsep. Peningkatan rata-rata kelas pada siklus II ini dikarenakan peneliti sudah mampu memperbaiki kekurangan-kekurangan dañ siklus I dengan memberikan motivasi dan dorongan semangat belajar yang lebih kepada siswa sehingga siswa semakin tertarik untuk belajar. Peningkatan rata-rata kelas pada siklus II ini dikarenakan peneliti sudah mampu memperbaiki kekurangan-kekurangan dañ siklus I dengan memberikan motivasi dan dorongan semangat belajar yang lebih kepada siswa sehingga siswa semakin tertarik untuk belajar. Dilihat dan ketuntasan belajar siswa yang memenuhi KKM (KKM 70) Berdasarkan data yang diperoleh untuk pra siklus sebanyak 13 orang dañ 35 siswa atau 36,36\% kualifikasi kurang baik. Setelah melakukan tindakan pada siklus I diperoleh data ketuntasan belajar adalah 23 dan 35 siswa atau 65,71\% kualifikasi cukup baik.

Dengan demikian dapat diketahui bahwa prestasi siswa pada siklus I Iebih besar dibandmgkan dengan pra sikius hal ini di karenakan peneliti menerapkan model pembelajaran inkuiri terbimbing berbasis peer tutorial yang merupakan model pembelajaran yang barn diterapkan di kelas tersebut sehingga siswa tidak merasa bosan dalam mengikuti kegiatan pembelajaran karena model pembelajaran ini sangat menekankan kepada siswa untuk mencari dan menemukan sendiri konsep dengan bantuan teman sebayanya yang dianggap lebih tahu. Selanjutnya pada siklus II siswa yang memenuhi KKM adalah 29 dañ 33 siswa atau 87,87\% 
kualifikasi baik. Peningkatan ketuntasan belajar siswa path siklus II ini juga dikarenakan peneliti sudah mampu memperbaiki kekurangan kekurangan dan siklus I dengan memberikan motivasi dan dorongan semangat belajar yang lebih kepada siswa sehingga siswa semakin tertarik untuk belajar.

\section{KESIMPULAN}

Berdasarkan paparan data dan temuan penelitian yang diperoleh dan basil penelitian, maka dapat disimpulkan bahwa: Kualitas keterlaksanaan pembelajaran dengan model pembelajaran Inkuiri terbimbing berbasis Peer Tutorial di salah satu SMP Negeri di kota Malang tergolong baik. Penerapan model pembelajaran Inkuiri terbimbing berbasis Peer Tuorial dapat meningkatkan motivasi dan prestasi belajar, hal ini dapat dilihat dari presentase rata-rata motivasi belajar siswa yang meningkat sebesar $16,66 \%$, sedangkan untuk prestasi meningkat $37,14 \%$.

\section{DAFTAR RUJUKAN}

A.M. Sardiman. 2011. Interaksi Dan Motivasi Belajar Mengajar. PT Rajagrafindo: Jakarta.

Amri, S. dan Ahmadi K.I. 2010. Proses Pembelajaran Kreatif Dan Inovatif Dalam Kelas. Jakarta: Prestasi Pustaka Raya

Arikunto. 1992. Pengelolaan Kelas Dan Siswa. Jakarta: Rajawali.

Asep Jihad dan Abdul Haris. 2010. Evaluasi Pembelajaran. Yogyakarta: Multi Press

Asminah. DR. 2010. Pembelajaran Fisika Dengan Metode Inkuiri Terbimbing Dan Inkuiri Training Ditinjau Dari Kemampuan Awal Dan Aktivitas Siswa. Tesis. Surakarta: Universitas Sebelas Maret

Dimyati \& Mudjiono. 2009. Belajar Dan Pembelajaran. Jakarta: Rineka Cipta

Djamarah, Syaiful Bahari dan Aswan Zain. 2010. Strategi Belajar Mengajar. Jakarta: Rineka Cipta

Harsanto, Radno. 2007. Pengelolaan Kelas Yang Dinamis. Kanisius (Anggota IKAPI): Yogyakarta.

Hidayati. 2004. Pendidikan Ilmu Pengetahuan Sosial Di Sekolah Dasar. Universitas Yogyakarta.

Huda, Miftahul. 2013. Model-Model Pengajaran Dan Pembelajaran. Malang: Pustaka Belajar

Hisyam, Zaini. 2008. Strategi Pembelajaran Aktif. Yogyakarta: Insan Mandiri.

Mujinem, Pengembangan Pendidikan IPS SD

Patrick, H., Mantzicopoulos, P,. \& Samarapungavan, A. 2009. Motivation for learning science in kindergarten: is there a gender gap and does intergrated inquiri and literacy instruction make a difference. Journal Of Research In Science Teaching, 46, 166-191.

Permono, Ahmadi. 2010. Strategi Belajar Mengajar. Yogyakarta: Multi Pressindo

Ratno Harsono. 2007. Pengelolaan Kelas Yang Dinamis. Yogyakarta: Kanisius

Sagala, Syaful. 2004. Konsep Dan Makna Pembelajaran. Bandung: Penerbit Alfa Beta

Sanjaya, Wina. 200. Strategi Pembelajaran Berorientasi Standar Proses Pendidikan. Jakarta: Kencana

Silberman, Melvin. 2001. Active Learning 101 Strategi Pembelajaran Aktif. Yogyakarta: Yappendi

Sumiati \& Sutikno. 2009. Metode Pembelajaran. Bandung: CV Wacana Prima 
Suparno, P. 2010. Metodologi Pembelajaran Fisika. Yogyakarta. Universitas Sanata Yogyakarta

Supriyadi. 2010. Teknologi Pembelajaran Fisika. Yogyakarta: MIPA Universitas Negeri Yogyakarta

Trianto. 2007. Model-Model Pembelajaran Inovatif Berorientasi Konstruktivistik. Jakarta: Prestasi Pustaka

Trianto. 2011. Model Pembelajaran Terpadu Konsep, Strategi Dan Implementasinya Dalam Kurikulum Tingkat Satuan Pendidikan (KTSP), Jakarta: Bumi Aksara,

Trianto. 2014. Mendesain Model Pembelajaran Inovatif, Progresif Dan Kontekstual. Jakarta: Prenada Media Group

Trianto. 2010. Model Pembelajaran Terpadu. Jakarta: PT. Bumi Aksara

Wahyudin \& Sutikno. 2010. Keefektifan Pembelajaran Berbantuan Multimedia Menggunakan Metode Inkuiri Terbimbing Untuk Meningkatkan Minat Dan Pemahaman Siswa. Jurnal Fisika Indonesia 6:58-62

Zaini, Hisyam. 2008. Strategi Pembelajaran Aktif. Yogyakarta: Insan Mandiri 